\title{
Raw milk flora affects composition and quality of Bergkäse. 3. Physical and sensory properties, and conclusions
}

\author{
Wolfgang Ginzinger ${ }^{\mathrm{a}}$, Doris Jaros ${ }^{\mathrm{b}}$, Pierre Lavanchy ${ }^{\mathrm{c}}$, \\ Harald Rohm ${ }^{\text {b* }}$
}

\author{
${ }^{a}$ Federal Research Institute of Alpine Dairying, Rotholz, A-6200 Jenbach, Austria \\ ${ }^{b}$ Department of Dairy Science and Bacteriology, University of Agricultural Sciences, \\ Gregor Mendel Strasse 33, A-1180 Vienna, Austria \\ ${ }^{\mathrm{c}}$ Federal Dairy Research Station (FAM), Liebefeld, CH-3003 Berne, Switzerland
}

(Received 27 May 1998; accepted 20 January 1999)

\begin{abstract}
Parallel productions of Austrian Bergkäse from raw or pasteurised milk were performed to monitor the effect of heat treatment on physical and sensory properties of the mature cheeses and, in some parameters, during ripening. Apart from some seasonal variations, analyses of variance showed that neither mechanical properties nor cheese body colour were influenced by the pasteurisation of the milk. However, sensory characterisation of smell and aroma as well as of the basic taste categories of the mature Bergkäse samples showed that pasteurisation leads to reduced intensities of the typical Bergkäse flavour but increases bitterness scores significantly. In line with results from preceding papers, it may be concluded that it is essential to use raw milk for the production of Bergkäse with satisfactory product properties. (C) Inra/Elsevier, Paris.
\end{abstract}

Bergkäse / raw milk flora / pasteurisation / physical property / sensory property

Résumé - La flore du lait cru influe sur la composition et la qualité du fromage Bergkäse. 3. Propriétés physiques et sensorielles, et conclusions. Des productions en parallèle de fromage autrichien Bergkäse à partir de lait cru ou de lait pasteurisé ont été réalisées pour suivre l'effet du traitement thermique sur les propriétés physiques et sensorielles des fromages affinés et, pour quelques paramètres, durant l'affinage. Á part quelques variations saisonnières, les analyses de variance ont montré que ni les propriétés mécaniques ni la couleur du fromage n'étaient influencées par la pasteurisation du lait. Cependant, la caractérisation de l'odeur et de l'arôme ainsi que des catégories de base du goût des échantillons de fromage Bergkäse affiné a montré que la pasteurisation conduit à une réduction de l'intensité de la flaveur typique du fromage Bergkäse mais accroît l'amertume de façon significative.

* Correspondence and reprints. rohm@mail.boku.ac.at 
Au vu des résultats présentés dans les précédentes parties de cet article [12, 19], on peut conclure qu'il est essentiel d'utiliser du lait cru pour la production de fromage bergkäse de qualité satisfaisante. (c) Inra/Elsevier, Paris.

\section{fromage Bergkäse / flore du lait cru / pasteurisation / propriété physique / propriété sensorielle}

\section{INTRODUCTION}

Austrian Bergkäse represents a local Gruyère-type cheese variety produced from raw milk, either on alpine sites during summer or in valley plants during the winter. Cheeses available on the market show a broad range with respect to product quality [18]. These variations partly reflect the indigenous and natural character of the product but, on the other hand, are certainly too pronounced to be accepted by the consumer. Differences between Bergkäse cheeses may be attributed to a number of factors comprising qualitative and quantitative aspects of the raw milk flora as well as to the cheesemaking conditions, which obviously depend on, e.g. plant size, plant location or even the impact of the cheesemaker. Recently, Bertozzi and Panari [5] and Rose [40] pointed out the variability of the aroma and flavour properties of raw milk cheeses as key characteristics, especially in the case of traditional cheeses with defined origin.

When subjecting cheese milk to pasteurisation it is mainly desirable to eliminate pathogens that may be present in raw milk. It is well known that the fate of pathogen microorganisms in raw milk cheese depends heavily on the type of cheese and on cheesemaking technology, and that the probability that pathogens survive in cheese is much lower in long ripened, cooked cheeses than in soft cheeses with high moisture and low salt content [20]. As has been demonstrated by Bachmann and Puhan [3], it is most unlikely that pathogens survive in Swiss-type hard cheeses. When focusing on sensory quality, it is evident from a number of papers that there is a significant dif- ference between cheeses from raw or pasteurised milk. To a minor extent, these differences are documented for instrumentally measured texture properties in relation to composition and proteolysis [17, 41], and almost no data are available with respect to heat treatment effects on cheese body colour. This is, however, not true for cheese quality expressed in terms of flavour and aroma. It has been shown in a sufficient number of studies $[6,7,11,17,25,32]$ that hard cheeses made from raw milk show a more pronounced aroma and flavour, which is presumably related to increased proteolysis, and that bitterness defects are more certain in cheeses made from pasteurised milk.

In a national project carried out within a European framework, we studied the effects of the pasteurisation of the milk on the microbiology of the cheese mass of Bergkäse [12] and on chemical composition [19] by using milk pasteurisation as an appropriate tool for partially eliminating the indigenous raw milk flora even though the experimental design did not make it possible to differentiate between microbial and other changes caused by pasteurisation. The objective of the current paper is to report the effects of raw milk flora on physical and sensory properties as well as to draw some general conclusions.

\section{MATERIALS AND METHODS}

\subsection{Cheese production and sampling}

As outlined in a preceding paper [12], a set of 16 Bergkäse cheeses (two wheels each) were produced either from raw or pasteurised milks during a period of 1 year. For instrumental anal- 
ysis, cylindrical samples (diameter approximately $10 \mathrm{~cm}$ ) cut from one cheese wheel along a circumferential line of a diameter of $18 \mathrm{~cm}$ at ages of $12,16,20$ and 24 weeks were used. Sensory analyses were performed by using quarters of the second Bergkäse wheel, which remained unaffected by the sampling procedure. It has already been shown that the technique of sampling during maturation does not significantly affect the compositional properties of the cheeses [19].

\subsection{Instrumental analyses}

A 60 -mm thick slice was taken from the middle of each sample cylinder, wrapped in aluminium foil and held overnight at $15^{\circ} \mathrm{C}$. Cheese body colour was measured on a freshly-cut surface with a MicroColor test station (Dr. Lange $\mathrm{GmbH}$, Berlin, Germany) equipped with a D65/10 $0^{\circ}$ xenon light source. The yellowness index $Y_{\mathrm{i}} \cdot(-)$, previously proposed as a onedimensional measure of cheese colour [35], was calculated by

$$
\mathrm{Y}_{\mathrm{i}^{*}}=[100(1.301 \mathrm{X}-1.149 \mathrm{Z})] \mathrm{Y}^{-1}
$$

where $\mathrm{X}, \mathrm{Y}$ and $\mathrm{Z}$ represent the three dimensionless colour primaries [2].

All uniaxial compression tests were performed with an INSTRON 1011 universal testing machine (Instron Ltd., High Wycombe, UK) equipped with an environmental chamber adjusted to $15^{\circ} \mathrm{C}$. Cylindrical specimens $12.5 \mathrm{~mm}$ in diameter and $15 \mathrm{~mm}$ in height were compressed between parallel plates generously lubricated with paraffin oil at a constant displacement rate of $15 \mathrm{~mm} \cdot \mathrm{min}^{-1}$. For each cheese sample, three to five replicate measurements were performed. Raw data were transformed into stress $\sigma(\mathrm{Pa})$ calculated from compressional force $\mathrm{F}(\mathrm{N})$ and corrected for changes in the cross-sectional area by applying

$$
\sigma=\left(\mathrm{Fr}_{0}^{-2} \pi^{-1}\right)\left(\mathrm{h}_{1} \mathrm{~h}_{0}^{-1}\right)
$$

[8], where $r_{0}(m)$ represents the initial radius of the sample, and $h_{0}(m)$ and $h_{1}(m)$ refer to initial specimen height and height at any time $\mathrm{t}(\mathrm{s})$, respectively.

As a relative measure of deformation, Hencky strain $\varepsilon(-)$ was calculated by:

$$
\varepsilon=-\ln \left(\mathrm{h}_{1} \mathrm{~h}_{0}{ }^{-1}\right)
$$

Three parameters were taken from the stress-strain curves. The stress maximum denoted as stress at apparent fracture $\sigma_{\mathrm{f}}(\mathrm{Pa})$ correlates well with sensory perception of firmness [26, 37 , and the corresponding fracture strain $\varepsilon_{\mathrm{f}}(-)$ can be regarded as an instrumental measure of sensory elasticity [31]. The modulus of deformability $M_{D}(\mathrm{~Pa})$, which was calculated from the initial slope of the stress-strain curves, represents a measure of firmness at small deformations [34].

Fat extracted by means of petroleum ether served as a basis for the determination of the iodine value, according to the Wijs method [1]. The number of eyes per cross section of each mature cheese wheel was taken from photographs.

\subsection{Sensory evaluation}

Sensory assessments were performed by an accredited panel, which varied in size between 10 and 17 members. Samples of $15 \times 15 \times 80 \mathrm{~mm}$ and $16{ }^{\circ} \mathrm{C}$ were presented in Petri dishes. The panelists had to assess the intensity of smell (olfactory stimulation) and aroma (trigeminal stimulation), as well as of the basic taste categories (sweet, salty, sour, bitter) using definitions and the testing descriptions outlined by Berodier et al. [4]. On each of the 7-point scales, anchors at 2 and 6 points were defined by providing reference materials (table $I$ ).

\subsection{Statistical evaluation}

Various univariate and multivariate procedures of the SAS 6.12 HP-UX software package [42] were used for statistical evaluation.

\section{RESULTS AND DISCUSSION}

\subsection{Physical properties}

Apparent fracture properties of Bergkäse grouped with respect to milk treatment and production period are plotted as a function of maturation time in figure 1. Generally, standard deviations within both treatments and seasonal replication were less than $10 \%$ of the corresponding average stress and strain values. For the cheeses produced in winter or spring, stress at apparent fracture decreased from approximately $180 \mathrm{kPa}$ for 
Table I. Reference materials for sensory descriptors.

Tableau I. Références utilisées pour les descripteurs sensoriels.

\begin{tabular}{|c|c|c|c|c|}
\hline \multirow{2}{*}{$\begin{array}{l}\text { Sensory } \\
\text { category }\end{array}$} & \multirow[t]{2}{*}{ Carrier } & \multirow{2}{*}{$\begin{array}{c}\text { Reference } \\
\text { material }\end{array}$} & \multicolumn{2}{|c|}{ Concentration $\left(\mathrm{g} \cdot 100 \mathrm{~g}^{-1}\right)$} \\
\hline & & & 2 points & 6 points \\
\hline Smell & Pasteurised milk & Cheese aroma ${ }^{a}$ & 0.50 & 8.0 \\
\hline Aroma & Quarg & Cheese aroma & 0.50 & 3.5 \\
\hline Sweet & Ricotta & D-fructose & 0.39 & 1.2 \\
\hline Salty & Ricotta & $\mathrm{NaCl}$ & 0.25 & 0.60 \\
\hline Sour & Ricotta & Lactic acid & 0.35 & 0.86 \\
\hline Bitter & Ricotta & Caffeine & 0.046 & 0.076 \\
\hline
\end{tabular}

${ }^{a}$ Cheddar Aroma Permaseal (10418-71, Givaudan-Roure).

12-week-old Bergkäse to $130 \mathrm{kPa}$ for the mature cheese. Significantly lower firmness of the cheese mass was found for Bergkäse produced during summer and autumn with corresponding fracture stress values of approximately $120 \mathrm{kPa}$ (12 weeks) and $80 \mathrm{kPa}$ ( 24 weeks). Seasonal variations appeared to be less pronounced in the case of apparent fracture strain, which ranged from approximately 1.2 (12 weeks) to 0.9 (24 weeks). The decrease of strain at appar- ent fracture observed with increasing cheese age has been found typical for a wide variety of hard and semi-hard cheeses $[23,31]$ and points to decreasing sensory elasticity accompanied by an increase in brittleness, i.e. increasing shortness of the cheese body [30].

Prior to cheesemaking from pasteurised milk, an amount of $50 \mathrm{~g} \mathrm{CaCl}_{2}$ was added to each vat containing $500 \mathrm{~L}$. Differences in

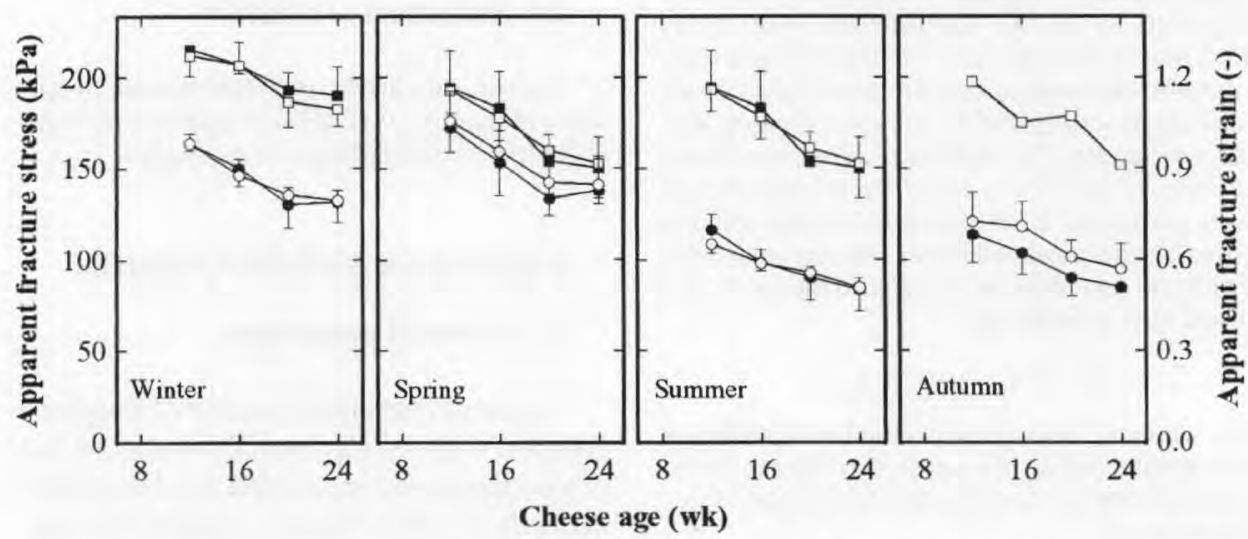

Figure 1. Development of stress and strain at apparent fracture in Bergkäse made from raw milk or pasteurised milk $(n=4)$ in different production periods. Stress: $\bigcirc$, raw; $\boldsymbol{\ominus}$, pasteurised. Strain: $\square$, raw; , pasteurised.

Figure 1. Développement de la contrainte et de la déformation à la fracture apparente dans le fromage Bergkäse produit à partir de lait cru ou de lait pasteurisé $(n=4)$ au cours de différentes périodes de production. Contrainte : $\bigcirc$, cru; $\bullet$, pasteurisé. Déformation : $\square$, cru; $\mathbf{\square}$, pasteurisé. 
the Ca content may affect both firmness and elasticity or brittleness of the cheese mass, especially when there are large variations in the cheese $\mathrm{pH}$ which, on the other hand, may affect the proportion of calcium in the undissolved form [9, 27-29]. As, according to Ginzinger et al. [19], neither $\mathrm{pH}$ nor the Ca content did depend significantly on the milk treatment, it is obvious that any effects of the addition of calcium on the Bergkäse texture may be neglected.

The results of instrumental texture measurements and the instrumental cheese body colour evaluations were subjected to analysis of variance (ANOVA). The applied model comprised milk treatment, i.e. pasteurisation, and cheese age as main effects and the seasonal factor as a sub-effect within the milk treatment and, additionally, interactions between treatment and maturation time. Whereas milk pasteurisation and the interaction effect proved to be insignificant (table II), we found a significant influence of both production season and maturation time $(P<0.01)$. Fracture stress and fracture strain as well as the modulus of deformability showed decreasing values with ripening time. In contrast, cheese body colour as characterised by the yellowness index significantly increased with increasing cheese age.

Similarly to fracture stress, small deformation firmness as expressed by the modulus of deformability was significantly lower in the summer and autumn cheeses and, consequently, these two measurements were correlated pronouncedly $(r=0.85)$. As outlined in table III, however, cheese body colour proved to be much more intense for Bergkäse produced during the summer (beginning of June) and in the autumn period (beginning of September). Increased firmness values as well as weaker colour intensities in winter and spring cheeses produced at the beginning of December and March, respectively, are clearly related to milk fat composition. The iodine value as a corresponding empirical measure was found to be 31.5 for cheeses from the winter and spring periods and approximately 40.5 for cheeses from the summer and autumn seasons. The iodine value, in turn, is significantly related to the $\beta$-carotene content of the milk fat [38] and also to the liquid-tosolid fat ratio at constant temperature [46]. These findings are in line with conclusions drawn in some previous work $[22,36]$ and underline the importance of fat composition for cheese texture and colour.

\subsection{Sensory characteristics of Bergkäse}

In the first step of the analysis of the sensory data, arithmetic mean values and standard deviations were calculated for each single cheese and each sensory category by

Table II. Effects on physical properties of Bergkäse as estimated by analysis of variance.

Tableau II. Effets sur les propriétés physiques du fromage Bergkäse estimés par analyse de variance.

\begin{tabular}{lcrrr}
\hline Parameter $^{\mathrm{a}}$ & Milk treatment $^{\mathrm{b}}$ & Season & Maturation & Interaction \\
\hline$\sigma_{\mathrm{f}}(\mathrm{kPa})$ & 0.11 & $<0.001$ & $<0.001$ & 0.62 \\
$\varepsilon_{\mathrm{f}}(-)$ & 0.78 & 0.008 & $<0.001$ & 0.44 \\
$\mathrm{M}_{\mathrm{D}}(\mathrm{kPa})$ & 0.23 & $<0.001$ & $<0.001$ & 0.97 \\
$\mathrm{Y}_{\mathrm{f}_{\mathrm{f}}}(-)$ & 0.62 & $<0.001$ & 0.002 & 0.79
\end{tabular}

${ }^{a} \sigma_{\mathrm{F}}$ stress at apparent fracture; $\varepsilon_{\mathrm{f}}$ : strain at apparent fracture; $\mathrm{M}_{\mathrm{D}}:$ modulus of deformability; $\mathrm{Y}_{\mathrm{i}}:$ yellowness index, " Numerical values, probabilities $P\left(\mathrm{H}_{0}\right): F>F_{\text {obs' }}$.

${ }^{\mathrm{a}} \sigma_{\mathrm{f}}$ : contrainte à la fracture apparente ; $\varepsilon_{\mathrm{f}}$ : déformation à la fracture apparente $\mathbf{M}_{\mathrm{n}}$ : module de déformabilité ; $\mathrm{Y}_{\mathrm{i}}$ : indice de jaune. ${ }^{b}$ Valeurs numériques, probabilités $P\left(\mathrm{H}_{0}\right), F>F_{\text {obs. }}$. 
Table III. Mean values of the yellowness index and iodine value of Bergkäse made from raw or pasteurised milk.

Tableau III. Valeurs moyennes de l'indice de jaune et de la valeur d'iode du fromage Bergkäse produit à partir de lait cru ou de lait pasteurisé.

\begin{tabular}{llllll}
\hline Production period & \multicolumn{2}{c}{ Raw milk cheeses } & & \multicolumn{2}{c}{ Pasteurised milk cheeses } \\
\cline { 2 - 3 } \cline { 5 - 6 } & $Y_{*}(-)^{\mathrm{ab}}$ & IV $(-)$ & & $Y_{*}(-)$ & IV $(-)$ \\
\hline Winter $(n=4)$ & $48.7^{*}$ & $31.6^{*}$ & & $49.9^{*}$ & $31.4^{*}$ \\
Spring $(n=4)$ & $46.0^{*}$ & $31.4^{*}$ & & $44.4^{*}$ & $31.7^{*}$ \\
Summer $(n=4)$ & $60.8^{+}$ & $41.1^{+}$ & & $60.1^{+}$ & $41.0^{+}$ \\
Autumn $(n=4)$ & $61.7^{+}$ & $40.1^{+}$ & & $61.4^{+}$ & $40.3^{+}$ \\
\hline
\end{tabular}

${ }^{a} Y_{i}$ : yellowness index; IV: iodine value. ${ }^{b}$ Mean values within a column with different symbols differ significantly $(P<0.01)$.

${ }^{a} Y_{\mathrm{i}_{\mathrm{i}}}$ : indice de jaune ; IV : valeur d'iode. ${ }^{b}$ Valeurs moyennes d'une colonne avec différents symboles sont significativement différentes $(p<0,01)$.

covering all panel members. The comparison of corresponding Bergkäse samples made from raw or pasteurised milk, i.e. of cheeses made from identical base milk differing only in milk treatment, by means of simple $t$-tests resulted in a number of significant $(P<0.05)$ differences. In the case of basic taste categories, the counts for these differences ranged between 0 for the 'salty' and 'sour' continua up to 13 for the 'bitter' category, whereby increased numerical values were observed for Bergkäse made from pasteurised milk (figure 2). Regarding the sensory categories of 'smell' and 'aroma', significant differences appeared in 8 and 7 of the total 16 cheese comparisons, respectively, with higher intensities for Bergkäse made from raw milk.

After pooling the mean values of the various sensory categories within each of the two treatments, another set of $t$-tests was performed. It is evident from table IV that, in general, smell and aroma intensities were significantly higher for Bergkäse made from raw milk. The most pronounced difference appeared for 'bitterness' with values of 1.87 and 2.71 for Bergkäse made from raw or pasteurised milk, respectively. These results are obviously in agreement with findings on Swiss-type mini-cheeses as published by
Beuvier et al. [6] and Demarigny et al. [11], who also noted higher aroma intensity and pungency for raw milk cheeses or cheeses containing the indigenous raw milk flora, and increased bitterness in pasteurised milk cheeses. In the corresponding frequency distribution plot, this difference is reflected by the shift along the $\mathrm{x}$-axis (figure 3). ANOVAs, which were performed by using the model described earlier, revealed similar tendencies (table $V$ ). Apart from the insignificant repetition effect within each production period, some significant season effects occurred, especially for saltiness and bitterness $(P<0.001)$. Due to splitting of variance, significance levels of the treatment effect increased for the categories 'salty' and 'sour'. For Bergkäse made from raw milk, saltiness and sourness intensities were 2.77 and 2.78 , respectively, and, in the case of cheeses produced from pasteurised milk, the corresponding values were 2.54 and 2.56 , respectively.

\section{CONCLUSION}

The conclusions on the project - which aimed to evaluate the influence of the raw milk flora on the properties of Austrian 

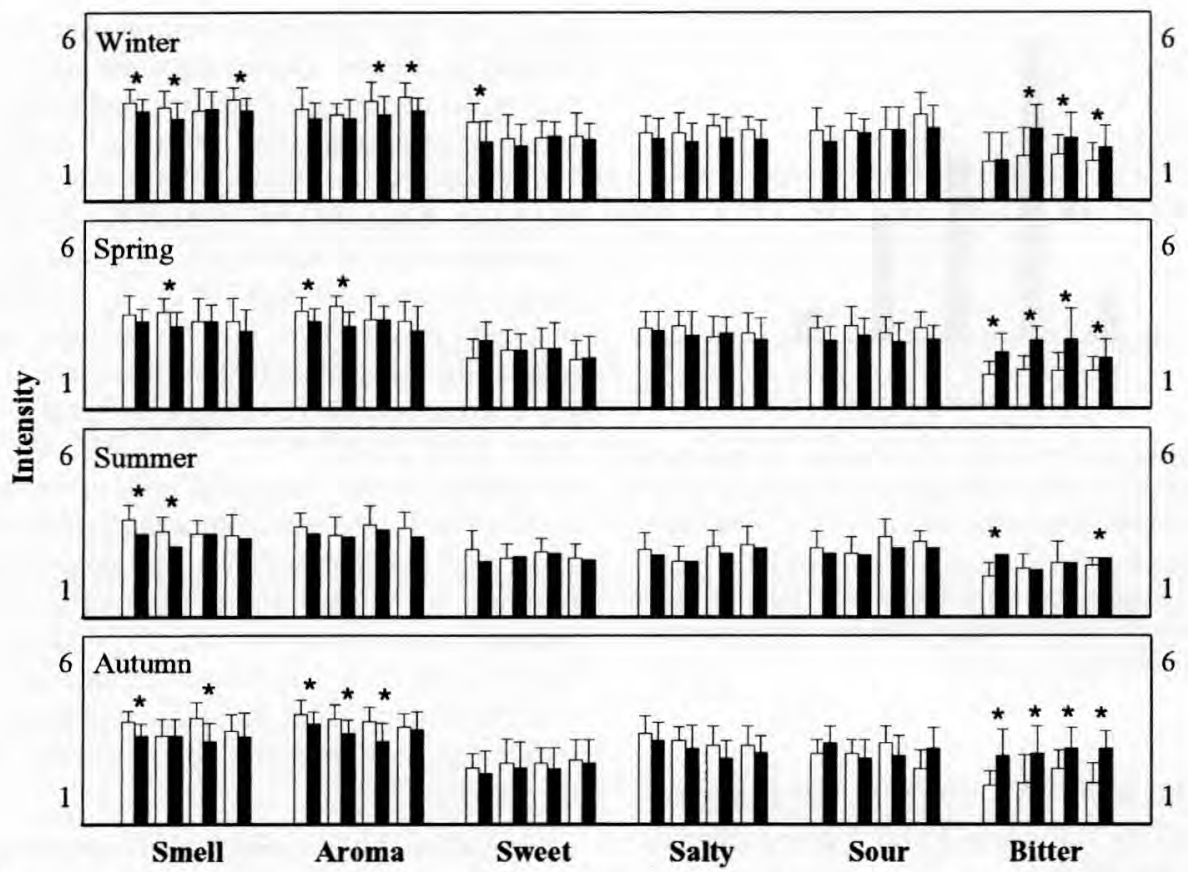

Figure 2. Mean sensory intensities of mature Bergkäse made from raw milk (open bars) or pasteurised milk (closed bars). The four groups of bars within each category and production period represent replications of the cheesemaking process. Significant differences $(P<0.05)$ are marked with an asterisk.

Figure 2. Intensités sensorielles moyennes du fromage Bergkäse affiné produit à partir de lait cru (barre blanche) ou de lait pasteurisé (barre noire). Les quatre groupes de barres dans chaque catégorie et période de production représentent les répétitions des fabrications fromagères. Les différences significatives $(p<0,05)$ sont indiquées par un astérisque.

Table IV. Mean values of sensory properties of Bergkäse made from raw or pasteurised milk.

Tableau IV. Valeurs moyennes des propriétés sensorielles du fromage Bergkäse produit à partir de lait cru ou de lait pasteurisé.

\begin{tabular}{lccc}
\hline Category & \multicolumn{2}{c}{ Cheese made from } & $P_{\mathrm{t}=0}{ }^{\mathrm{a}}$ \\
\cline { 2 - 3 } & $\begin{array}{c}\text { Raw milk } \\
(n=16)\end{array}$ & $\begin{array}{c}\text { Pasteurised milk } \\
(n=16)\end{array}$ & \\
\hline Smell & $3.43 \pm 0.24^{\mathrm{b}}$ & $3.14 \pm 0.17$ & $<0.001$ \\
Aroma & $3.53 \pm 0.28$ & $3.20 \pm 0.23$ & $<0.001$ \\
Sweet & $2.31 \pm 0.25$ & $2.22 \pm 0.19$ & 0.26 \\
Salty & $2.77 \pm 0.31$ & $2.54 \pm 0.28$ & 0.028 \\
Sour & $2.78 \pm 0.56$ & $2.56 \pm 0.33$ & 0.12 \\
Bitter & $1.87 \pm 0.25$ & $2.71 \pm 0.42$ & $<0.001$ \\
\hline
\end{tabular}

\footnotetext{
${ }^{\mathrm{a}} \boldsymbol{P}_{\mathrm{t}=0}$, significance in $t$-test; ${ }^{\mathrm{b}}$ Mean \pm standard deviation.
}

${ }^{\mathrm{a}} P_{\mathrm{t}=0}$, signification dans le test $-t ;{ }^{\mathrm{b}}$ moyenne \pm écart type. 


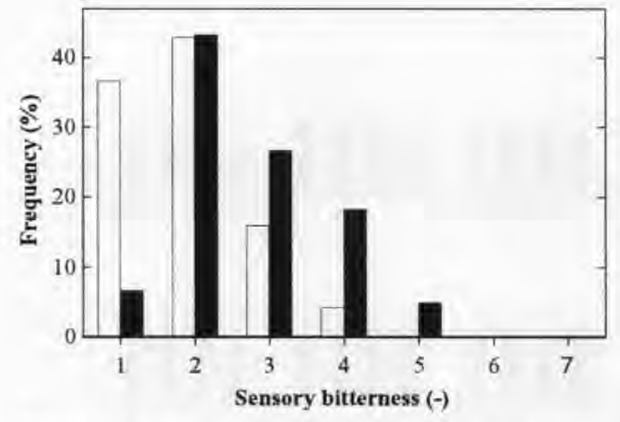

Figure 3. Frequency distribution of bitterness intensity in mature Bergkäse made from raw milk (open bars) and pasteurised milk (closed bars).

Figure 3. Fréquence de l'intensité de l'amertume dans le fromage Bergkäse affiné, produit à partir de lait cru (barres blanches) ou de lait pasteurisé (barres noires).

Table V. ANOVA table for sensory properties. Tableau V. Tableau ANOVA pour les propriétés sensorielles.

\begin{tabular}{lccc}
\hline Category & $\begin{array}{c}\text { Milk } \\
\text { treatment }^{\mathrm{a}}\end{array}$ & Season & Repetition \\
\hline Smell & $<0.001$ & 0.028 & 0.085 \\
Aroma & $<0.001$ & 0.024 & 0.43 \\
Sweet & 0.22 & 0.11 & 0.48 \\
Salty & 0.002 & $<0.001$ & 0.42 \\
Sour & 0.008 & 0.15 & 0.26 \\
Bitter & $<0.001$ & $<0.001$ & 0.17 \\
\hline
\end{tabular}

a Numerical values, probabilities $P\left(\mathrm{H}_{0}\right): F>F_{\text {obs. }}$.

a Valeurs numériques, probabilités $P\left(\mathrm{H}_{0}\right), F>F_{\text {obs: }}$.

Bergkäse - will cover both the results of this study in context with some findings published in preceding papers [12, 19]. Neither coliforms, enterococci nor facultatively heterofermentative lactobacilli (FHL) were detectable in pasteurised vat milk. In the raw milk cheeses, the combined action of acidification and curd cooking resulted in a complete inactivation of potentially pathogenic coliforms, Escherichia coli and Staphylococcus aureus within 1 week. Similar results have been published by Bach- mann and Puhan [3] for Emmental and Tilsit-type cheeses. During the maturation of raw milk cheeses, the FHL reached a maximum of approximately $10^{8} \mathrm{cfu} \cdot \mathrm{g}^{-1}$ within 4 to 8 weeks and then showed a certain decrease. Counts of obligately heterofermentative lactobacilli (OHL) generally ranged between $10^{4}$ and $10^{6} \mathrm{cfu} \cdot \mathrm{g}^{-1}$ cheese but were much lower in 3 of 16 cheeses, indicating a complete lack of this group in the corresponding raw milk. In Bergkäse made from pasteurised milk, OHL were completely absent, and FHL only occurred in 4 of the 16 cheeses with a maximum of $10^{6} \mathrm{cfu} \cdot \mathrm{g}^{-1}$ probably caused by post-contamination. The maximum of enterococci counts was less than $10^{4} \mathrm{cfu} \cdot \mathrm{g}^{-1}$, which is much lower than achieved in field studies $[10,39]$ and indicates that plant equipment rather than raw milk can be considered as the major source.

Regarding microbiological composition, the differences observed between cheeses from raw or pasteurised milk are obviously responsible for systematic variations in the organic acid content. Generally, the concentration of lactic and citric acid showed a faster decrease to a significantly lower final value in raw milk cheeses, whereas concentrations of propionic, acetic and succinic acids proved to be higher. One of the responsible pathways is propionic acid fermentation in raw milk cheeses due to the occurrence of propionic acid bacteria metabolising lactic acid to propionate and acetate as well as to carbon dioxide, which may probably result in undesirably excessive eye formation and the occurrence of slits [44]. Apart from pasteurisation, partial inactivation of propionic acid bacteria may be achieved by increasing the salt content which, however, may possibly alter the rate of proteolysis, or via interactions with selected FHL strains [24]. Enzymatic degradation of amino acids may be regarded as an additional source of acetic and succinic acids [43, 44]. According to Jimeno et al. [24], a certain amount of FHL species or strains are able to degrade citric acid. As the decrease in citrate con- 
tent proved to be in line with the development of FHL in raw milk cheeses and, on the other hand, was completely absent in Bergkäse made from pasteurised milk, this pathway may represent the third microbiologically induced activity of major importance. Finally, FHL and their enzymes obviously contribute to proteolysis, as indicated by the higher amount of $\alpha_{51}$-casein degradation in raw milk cheeses [45]. With the experimental design used in our studies it is, however, not possible to separate definitively between microbiological effects and biochemical effects of the heat treatment and, particularly, inactivation of the acid milk protease perhaps contributing to the degradation of $\alpha_{s !}$-casein [33].

Differences between raw or pasteurised milk cheeses observed in the intensities of propionic acid fermentation and in the metabolisation of citrate, probably by FHL, are obviously reflected by the appearance of the cheeses as characterised by the intensity of eye formation. Whereas none of the 16 Bergkäse wheels made from pasteurised milk showed an eye number exceeding a value of 1 per total cross section of approximately $6 \mathrm{dm}^{2}$, the number of eyes ranged between 0 and 23 for the cheeses manufactured from raw milk. Cheeses produced during winter, spring and autumn showed an average eye number of 18,7 and 10 , respectively, but raw milk cheeses produced during summer proved to remain totally blind. It must be mentioned that a field study on ready-to-consume Bergkäse samples performed previously [22] revealed similar results, i.e. reduced or lacking eye formation in cheeses produced on alpine sites during summer.

Besides these systematic variations, which can be attributed primarily to composition and viable counts of the microflora, there were also significant differences in the proteolytic activity obviously caused by the heat treatment procedure. It is common knowledge that the alkaline milk protease, plasmin, plays a major role in Swiss-type cheeses due to some plasminogen activation stimulated by cooking, which also partially inactivates the coagulant $[13,15,16]$. It is also evident that milk pasteurisation increases plasmin activity, either by increasing plasminogen-to-plasmin activation or by inactivation of plasmin inhibitors [21]. As far as Bergkäse was concerned, we found completely different patterns of plasmin activity between cheeses made from raw and pasteurised milk. During maturation of raw milk cheeses, the plasmin content decreased slowly, whereas, in the latter case, the plasmin content showed a pronounced increase. These differences are obviously reflected by the degree of degradation of $\beta$-casein to $\gamma$-casein, which was found to be significantly higher in pasteurised milk cheeses. In accordance with enhanced primary proteolysis, raw milk treatment affected the distribution of nitrogen $(\mathrm{N})$ compounds and, for example, a higher amount of water-soluble $\mathrm{N}$ appeared in Bergkäse made from pasteurised milk. As demonstrated by the use of plasmin inhibitors [14], this increase in protein degradation may be directly related to the differences in plasmin activity. On the other hand, differences were less pronounced and insignificant for $\mathrm{N}$ compounds containing smaller breakdown products. Consequently, the heat-induced increases in plasmin activity lead to an accumulation of products of proteolysis soluble in the aqueous phase but insoluble in $12 \%$ trichloroacetic acid or $5 \%$ phosphotungstic acid.

Both differences in microflora composition and intensity of proteolysis as caused by pasteurisation of the cheese milk showed a certain impact on the sensory quality of the Bergkäse produced. Generally, samples manufactured from raw milk showed significantly higher intensities for smell and aroma, which can be mainly attributed to both the microflora and enzymes present in the raw milk, but lower scores for the bitterness category. Whereas the lack of smell and aroma in the cheeses made from pasteurised milk only resulted in a flat sensory 
character, the increased bitterness level was so high that it had to be considered as a strong defect. Consequently, it is evident that it is inappropriate to use raw milk pasteurisation for the elimination of the indigenous microflora, which seems to be essential to produce Bergkäse of satisfactory sensory quality.

\section{ACKNOWLEDGEMENTS}

The project was supported by the Austrian Ministry of Agriculture and Forestry, research grants L773/93 and AM44/93, and carried out within the framework of the COST95 and ECAIR 2039CT concerted actions financed by the European Community.

\section{REFERENCES}

[1] Anonymous, Determination of the iodine value of butter fat - Wijs method, FIL/DF Standard 8, International Dairy Federation, Brussels, Belgium, 1964.

[2] Anonymous, Beschreibung der Vergilbung von nahezu weiben oder nahezu farblosen Materialien, Norm 6167, Deutsches Institut für Normung e.V., Berlin, Germany, 1980.

[3] Bachmann H.P., Puhan Z., Verhalten von potentiell humanpathogenen Bakterien in Hart- und Halbhartkäse aus Rohmilch, Schweiz. Milchwirtsch. Forsch. 23 (1994) 54-58, 60-61.

[4] Berodier F., Lavanchy P., Zannoni M., Casals J., Herrero L., Adamo C., Guide to the smell, aroma and taste evaluation of hard and semi-hard cheeses, G.E.CO.TE.F.T., Poligny, 1997.

[5] Bertozzi G., Panari L., Cheeses with Appellation d'Origine Contrôlée (AOC): factors that affect quality, Int. Dairy J. 3 (1993) 297-312.

[6] Beuvier E., Berthaud K., Cegarra S., Dasen A., Pochet S., Buchin S., Duboz G., Ripening and quality of Swiss-type cheese made from raw, pasteurised or microfiltered milk, Int. Dairy J. 7 (1997) 311-323.

[7] Bouton Y., Grappin R., Comparaison de la qualité de fromages à pâte pressée cuite fabriqués à partir de lait cru ou microfiltré, Lait 75 (1995) $31-44$.

[8] Casiraghi E.M., Bagley E.B., Christianson D.D., Behaviour of Mozzarella, Cheddar and processed cheese in lubricated and bonded uniaxial compression, J. Texture Stud. 16 (1985) 281-301.
[9] Creamer L.K., Gilles J., Lawrence R.C., Effect of $\mathrm{pH}$ on the texture of Cheddar and Colby cheese, N. Z. J. Dairy Sci. Technol. 23 (1988) 23-35.

[10] Demarigny Y., Beuvier E., Dasen A., Duboz G., Influence of the raw milk microflora on the characteristics of Swiss-type cheeses. I. Evolution of microflora during ripening and characterization of facultatively heterofermentative lactobacilli, Lait 76 (1996) 371-387.

[11] Demarigny Y., Beuvier E., Buchin S., Pochet S., Grappin R, Influence of raw milk microflora on the characteristics of Swiss-type cheeses, II. Biochemical and sensory characteristics, Lait 77 (1997) 151-167.

[12] Eliskases-Lechner F., Ginzinger W., Rohm H., Tschager E., Raw milk flora affects composition and quality of Bergkäse. 1. Microbiology and fermentation compounds, Lait 79 (1999) 385-396.

[13] Farkye N.Y., Fox P.F., Observations on plasmin activity in cheese, J. Dairy Res. 57 (1990) 413-418.

[14] Farkye N.Y., Fox P.F., Preliminary study on the contribution of plasmin to proteolysis in Cheddar cheese: cheese containing plasmin inhibitor, 6-aminohexanoic acid, J. Agric. Food Chem. 39 (1991) 786-788.

[15] Farkye N.Y., Kiely L.J., Allshouse R.D., Kindstedt P.S., Proteolysis in Mozzarella cheese during refrigerated storage, J. Dairy Sci. 74 (1991) 1433-1438.

[16] Fox P.F., Law J., McSweeney P.L.H., Wallace J., Biochemistry of cheese ripening, in: Fox P.F. (Ed.), Cheese: Chemistry, Physics, and Microbiology, Vol. 1, General Aspects, Chapman \& Hall, London, 1993, pp. 389-438.

[17] Gaya P., Medina M., Rodriguez-Marin M.A., Nunez M., Accelerated ripening of ewes' milk Manchego cheese: the effect of elevated ripening temperatures, J. Dairy Sci. 73 (1990) 26-32.

[18] Ginzinger W., Jaros D., Rohm H., Characteristics and description of Vorarlberger Bergkäse. 6. General implications on quality, Milchwissenschaft 53 (1998) 381-385.

[19] Ginzinger W., Jaros D., Mayer H.K., Rohm H., Tschager E., Raw milk flora affects composition and quality of Bergkäse. 2. Chemical composition, Lait 1999.

[20] Grappin R., Beuvier E., Possible implications of milk pasteurization on the manufacture and sensory quality of ripened cheese, Int. Dairy J. 7 (1997) $751-761$.

[21] Grufferty M.B., Fox P.F., Milk alkaline protease, J. Dairy Res. 55 (1988) 609-630.

[22] Jaros D., Rohm H., Characteristics and description of Vorarlberger Bergkäse. 2. Appearance and texture properties, Milchwissenschaft 52 (1997) 625-629. 
[23] Jaros D., Ginzinger W., Tschager E., Mayer H.K. Rohm H., Effects of water addition on composition and fracture properties of Emmental cheese, Lait 77 (1997) 467-477.

[24] Jimeno J., Lazaro M.J., Sollberger H., Antagonistic interactions between propionic acid bacteria and non-starter lactic acid bacteria, Lait 75 (1995) 401-413.

[25] Johnson E.A., Nelson E.A., Johnson M., Microbiological safety of cheese made from heattreated milk. III. Technology, discussion, recommendations, bibliography, J. Food Protect. 53 (1990) 610-612.

[26] Lavanchy P., Berodier F., Zannoni M., Noel Y., Adamo C., Squella J., Herrero L.P.Y., L'évaluation sensorielle de la texture des fromages à pâte dure ou semi-dure. Étude interlaboratoires, Food Sci. Technol. 26 (1993) 59-68.

[27] Lawrence R.C., Gilles J., Factors that determine the $\mathrm{pH}$ of young Cheddar cheese, N. Z. J. Dairy Sci. Technol. 17 (1982) 1-14.

[28] Lawrence R.C., Gilles J., Creamer L.K., The relationship between cheese texture and flavour, N. Z. J. Dairy Sci. Technol. 18 (1983) 175-190.

[29] Lucey J.A., Fox P.F., Importance of calcium and phosphate in cheese manufacture: a review, J. Dairy Sci. 76 (1993) 1714-1724.

[30] Luyten H., van Vliet T., Effect of maturation on large deformation and fracture properties of (semi) hard cheeses, Neth. Milk Dairy J. 50 (1996) 295-307.

[31] Luyten H., van Vliet T., Walstra P., Note on the shortness of Dutch-type cheese, Neth. Milk Dairy J. 51 (1987) 282-284.

[32] McSweeney P.L.H., Fox P.F., Lucey J.A., Jordan K.M, Cogan T.M., Contribution of the indigenous microflora to the maturation of Cheddar cheese, Int. Dairy J. 3 (1993) 613-634.

[33] McSweeney P.L.H., Fox P.F., Olson N.F., Proteolysis of bovine caseins by Cathepsin D: preliminary observations and comparison with chymosin, Int. Dairy J. 5 (1995) 321-336.

[34] Mohsenin N.N., Physical Properties of Plant and Animal Materials, Gordon and Breach, London, 1990.
[35] Rohm H., Jaros D., Colour of hard cheese. 1. Description of colour properties and effects of maturation, Z. Lebensm. Unters. Forsch. 203 (1996) 241-244.

[36] Rohm H., Jaros D., Colour of hard cheese. 2. Factors of influence and relation to compositional parameters, Z. Lebensm. Unters. Forsch. 204 (1997) 259-264.

[37] Rohm H., Lederer H., Ginzinger W., Sensorische und instrumentelle Texturprüfungen von Emmentaler, Milchwirtsch. Ber. 109 (1991) 191-195.

[38] Rohm H., Strobl M., Jaros D., Butter colour affects sensory perception of spreadability, Z. Lebensm. Unters. Forsch. 205 (1997) 108-110.

[39] Rohm H., Kneifel W., Laimböck W., Desangles C., Ginzinger W., Eliskases-Lechner F., Jaros D., Characteristics and description of Vorarlberger Bergkäse. 1. Data collection and microbiology, Milchwissenschaft 52 (1997) 569-573.

[40] Rose E., Cheese lovers should not be condemned to a pasteurised and tasteless product, $\mathrm{Br}$. Med. J. 312 (1996) 312.

[41] Rosenberg M., Wang Z., Chuang S.L., Shoemaker C.F., Viscoelastic property changes in Cheddar cheese during ripening, J. Food Sci. 60 (1995) 640-644.

[42] SAS Institute, SAS/Stat Guide for Personal Computers, 6.12 edn., SAS Institute, Inc., Cary, NC, USA, 1996.

[43] Sebastiani H., Tschager E., Succinatbildung durch Propionsäurebakterien - eine Ursache der Nachgärung von Propionsäurebakterien? DMZ Lebensm. Ind. Milchwirtsch. 114 (1993) 76-80.

[44] Steffen C., Flückiger E., Bosset J,O., Rüegg M., Swiss-type varieties, in: Fox P.F. (Ed.), Cheese: Chemistry, Physics, and Microbiology, Vol. 2, Major Cheese Groups, Chapman \& Hall, London, 1993, pp. 83-110.

[45] Visser J., Proteolytic enzymes and their relation to cheese ripening and flavour: an overview, J. Dairy Sci. 76 (1992) 329-350.

[46] Walstra P., Jenness R., Dairy Chemistry and Physics, John Wiley, New York, 1984. 